\title{
Research on the Development Strategy of Private Universities
}

\author{
Xu Yuanyuan* \\ Qingdao Huanghai University \\ Qingdao, P.R.China \\ 2678780687@qq.com
}

\author{
Wang Weizhi \\ Qingdao Huanghai University \\ P.R.China \\ 1638823661@qq.com
}

\author{
Li Ying \\ Qingdao Huanghai University \\ P.R.China \\ 25904905@qq.com
}

\begin{abstract}
Under the guidance of the theory of competitive strategy, the marketing of higher education and sustainable development of education, on the base of comprehensive analysis of the development status of private universities, using the SWOT strategic analysis tool, the paper analyzes the opportunities, challenges, advantage and disadvantage of private universities, and puts forward the future development strategy. Private universities should fully implement the differential development strategy with the differentiation in development orientation, major settings and employment guide.
\end{abstract}

Keywords_private colleges; SWOT; differentiation; competition strategy

\section{INTRODUCTION}

In recent years, economy develops rapidly in China. The education market is expanding gradually. The development of private education industry is also very rapid, and the number of it has reached a considerable scale. According to the statistics in "National Education Development Statistics Bulletin in 2012" issued by the Ministry of Education , in 2012, the number of private universities has reached 707 (including 303 independent institutes ), increasing by $9 \%$ compared with that of last year. The enrollment has reached 1602800, increasing by 65500 compared with that of last year. The number of students in private universities has reach 5331800, increasing by 281100 compared with that of last year. Private education has its own characteristics in its education quality, has formed their own structure and level, and has gained the social and public recognition. The development of private education helps form a plural pattern of China's education, and contributes their strength for the development of higher education in China. However, besides its development and achievement, we can also see its shortcomings, such as shortage of funds, no development security, imperfect internal management, nonstandard running system, no characteristics, and low education quality.

\section{THE THEORETICAL BASIS OF THE DEVELOPMENT OF PRIVATE UNIVERSITIES}

\section{A. The competitive strategy theory}

Competitive strategy is also called the commercial strategy or management strategy, whose core is to build competitive advantage in a particular industry or market. Competitive advantage refers to the ability of enterprises that their competitors do not have or are not good at, so you can provide the product and service for the customers more effectively, efficiently and economically. [1] In the enterprise competitive strategy theory, the study on the competitive strategy of Michael Porter of Harvard University's business school is in the leading position. In the early 1980s, on the basis of the study on manufacturing industry in Japan, America and Europe, Michael Porter put forward the competitive strategy theory [2]. He put the industry organization theory into strategic research. He based the theory of competitive strategy on the industrial structure analysis, and attributed the key to the success of an enterprise to the competition. This is the first time that one transfers the key of strategic analysis from the enterprise to the industry, which emphasizes the external environment for enterprise development, especially the impact of industry characteristics on investment's rate of return. We can sum up the core of the theory as follows: the competitive advantage of enterprises is mainly decided by industry's profitable ability, that is to say, the attraction of industry and enterprises' relative competitive position in the industry. So, to the strategic management, the key task is to choose the most attractive industry, then consider its own position in the selected industry. Therefore, Potter believes that the industry selection is the key of enterprises' strategy [3] .

\section{B. The higher education marketing theory}

The higher education marketing theory is the application of the theory and methods of marketing in the practice of higher education management[4]. From the microscopic point of view, the marketing of higher education refers to the analysis, plan, implementation and control to the well-designed higher 
education products of higher education institutes, which can promote the spontaneous exchange of value between the higher education institutes and its target market, in order to achieve the goal of higher education institutions. The marketing of higher education includes the need to study the target market of higher education ,appropriate design of higher education product and service, to meet the demand of the target market of higher education, to create, stimulate and serve the higher education market through effective pricing, transmission and distribution [5].From the macro view, the higher education marketing studies the marketing problems from a social point of view, from the point of regulating the relationship between regulation of the higher education marketing activities and social interests.

\section{SWOT ANALYSIS OF THE DEVELOPMENT OF PRIVATE} UNIVERSITIES

\section{A. Analysis of external opportunities (O)}

The so-called opportunities usually refer to that the change of some external environment factors provides the advantageous opportunity for the survival and development of organizations.

\section{1) Encouraging policies}

Since the Reform and Opening up, the party and the state attaches more and more importance to private education, and have issued a series of supporting laws, regulations and policies for private university. The private higher education has gained unprecedented support and encouragement. On 4th December, 1982, "Constitution of People's Republic of China" was issued on the fifth meeting of the fifth session of the National People's Congress. The item 19-4 reads "the State encourages the collective economic organizations, state enterprises and institutions and other sectors of society to establish educational institutions of various types in accordance with the laws and regulations". On 28th December, 2002 , " Education Promotion Law of the people's Republic of China" was issued at the thirty-first meeting of the ninth NPC Standing Committee, which marks the" Nongovernmental Sectors Running Schools Regulations" was abolished. The announcement of the law shows that the state confirms the development policy of private education" to encourage it actively, to support it strongly, to guide it correctly, and to govern it according to the law". Then the private education has been confirmed. In 2010, the "National Long-Term Education Reform and Development Plan (2010-2020)" was issued by the CPC Central Committee and the State Council, which makes the overall strategic plan from the perspective of the overall strategy of China's modernization, and confirms the strategic target, policy, general task, thought of reform and major measures for the reform and development of the education of China in the next ten years. It has confirmed in the Plan "to clear and correct all kinds of discrimination policy for private schools ", and that "Private education is an important growth point of education development and an important force in promoting education reform", which further clarifies the equal legal status of the private and public schools, and clears the policy barrier restricting the development of private education.

\section{2) Big market demand}

The demand of higher education market is usually divided into two aspects: individual and social needs. The individual demand refers to the personal need to receive higher education at a certain age. The individual demand is usually characterized by the economic capability of the person or family and the personal urgency on the demand for higher education. That is to say, the individual needs have to meet the two basic conditions, one of which is that the individuality or family should have a certain economic foundation, and have the ability to pay the costs of higher education. The second is the individuality must receive higher education in a certain period; otherwise the risk cost and opportunity cost will greatly increase. With the development of economy and the rise of people's income, the concept of an individuality and family has changed, and people's education investment consciousness is unceasingly enhanced. The individuality's desire to accept higher education is increasingly strong. The social demand is that with the development of social economy, the number of social demand for higher education talents increases.

\section{B. Analysis of external threats (T)}

The external threat analysis refers to the trend against the development in the external environment. Detect the factors that may influence the organizational status, in order to cause the relevant personnel's attention and take measures to avoid or reduce the loss.

\section{1) A decrease in the number of students}

As is known to all, the lifeline of the school is students, which is an important factor affecting the development of the school. At present, the private universities are facing the crisis of enrollment mainly in three aspects: The first one is the expansion of college enrollment starting in the late 1990s, which made the enrollment scale of public institutions increase rapidly, so that the students of private colleges is seriously insufficient, and the survival and development are increasingly difficult; The second is the rapid development of private higher education and the rapid increase in the number of private universities made fierce competition among the private universities. The third one is the number of school-age students in universities is greatly decreased, while the acceptance rate of the public universities increase, which makes it difficult for the private universities in enrollment. In 1999, the number of students joining college entrance exam was 2880000. In 2008, it reached 10800000.It began to decline in 2009. In 2012, it dropped to 9150000, while the acceptance rate of the college entrance examination increased from $56 \%$ in 1999 to $75 \%$ in 2012.

\section{2) The non-identity from the traditional concept}

From the history of the modern university, private university has a relatively short history, and belongs to a new thing in the environment of market economy, while in Chinese traditional concept, people have dependence and trust in public colleges and universities, which are thought to have high employment rate and social identity. Therefore, people don't trust the teaching quality, teachers and school conditions of the private universities. This has caused that, if it is possible, many families often let their children choose public universities. 


\section{Analysis of the internal strengths (S)}

The internal advantage refers to the more favorable circumstances and conditions that the organization is in. To develop and use the advantages, it not only refers to the advantages that has existed already, but also to the acquire and develop some certain advantages, and find a better chance.

\section{1) Flexible mechanism}

Private universities take a market-oriented running mechanism. This flexible mechanism means that the private universities can adjust their education ideas and teaching methods according to the market demand, and train the applied and technocratic talents who can fit the demand of the market. At the same time of meeting the market demand, it also can promote the economic development and the maintenance of social stability. Plus, the private universities have the advantage of independent operation, which makes it be able to adjust its teaching contents and direction of education, to adjust its running and training mode with the demand of the market. This is the advantage of the private universities compared with the public universities.

\section{2) Greater autonomy}

At present, most private universities implement the headmaster-directed system under the leadership of the boar. The headmaster is responsible to the board, and takes charge of the daily teaching, human resources, finance and related management. The board takes charge of the long-term planning and infrastructure projects. The separation of investment and running can be basically achieved. Article 5 in "Private Education Promotion Law" says clearly that the state safeguards the autonomy of the private schools. This autonomy includes ownership, the right of possession, management, usufruct and disposition, which can] arouse the enthusiasm of the investors and managers, and can promote the reform of local or whole education system.

\section{Internal weaknesses analysis (W)}

The disadvantage is negative factors and impossibility that bring the adverse effects to the organization system, and make it difficult to achieve the goal.

\section{1) The relative shortage of funds}

The funding of most private universities is only tuition. Support from the government is little. The self-financing largely restricts the development of private universities. Because of the shortage and instability of funds, sometimes it is difficult to survive, much less to develop. Students are fundamental to the survival of private universities. Students have been becoming less and less. Capital has become the bottleneck of the development. The lack of funds makes a lot of things hard to achieve. The tuition income is far from meeting the demand of the higher education. Therefore, the development is the very difficult.

\section{2) The less qualified teachers}

Due to the limitation of national policy on private college teachers' transfer of hukou(registered permanent residence) and professional title evaluation, in many areas, teachers in private colleges do not enjoy the same treatment with teachers in public colleges in the personnel file management and professional title evaluation. These policy restrictions make many people not want to work in private colleges. We can see from the CD data of the second economic census(2008), that at the end of 2008, the private university has employed 220122 people, accounting for $10.7 \%$ of all employees in universities. The average employee of each unit is 183 people. Compared with that of public colleges, the number of employees of private universities is pitifully poor.

In addition, the structure of the teachers in private universities is not very good, which is mainly characterized by the low proportion of full-time teachers, and that most full-time teachers are young with low degree, professional titles and lack of teaching experience. The number of experienced full-time teachers with thigh level, high degree and high title is poor.

\section{THE DIFFERENTIAL DEVELOPMENT STRATEGY OF PRIVATE UNIVERSITIES}

Compared with public universities, private universities are far worse not only in the school size and level, but also the policy benefits or social concept. The competition between the two is not fair. At the same time, the competition between the private universities is very fierce. In the future, if private universities want to develop faster and win the advantage in the fierce competition, it must choose their development strategy scientifically and reasonably. Therefore, in order to ensure their own development, private universities must find a differential development strategy which is different from the public university.

The differential development strategy, is a competition strategy that the enterprises create customers' perceptive value by its different products or service from its competitors and gain competitive advantage[6]. The enterprises that implement this strategy provide products or service that their competitors don't have, whose uniqueness is valuable to customers, so the customers are willing to buy their products or service at a higher price. Its basic logic is that the enterprises are dedicated to creating the uniqueness of products and service that can meet the customers' demand, and sell the products and service at an extra price that the customers can accept and exceed the cost to get the uniqueness. Because of the uniqueness, customers will generate loyalty. Thus, the enterprises will obtain competitive advantage and win the excess profit.

\section{A. Content of differential development strategy}

\section{1) The differentiation of development orientation}

The positioning is correct or not concerns directly whether the private colleges will develop healthily, rapid, stable and sustainable. To occupy the advantageous position in the fierce competition in the education market, private universities must apply SWOT analysis of management strategy, assess themselves, and compare their advantages and disadvantages. In development orientation, private universities should be oriented to the market, the new industries, new jobs and new economic growth point in rural areas, and cultivate applied and technical talents for the local economy and social development. 


\section{2) Differentiation of major settings}

The majors of private universities ought to orientate to meeting the needs of the pillar industries and emerging industries of local economy. Private universities need to form unique characters different from other universities, which reflect the school running characteristics, adopt differential strategy and turn this difference into competitive advantages.

3) The differentiation of employment guide

In recent years, the employment of college graduates has aroused great concerns. The employment situation is very grim. If the private universities want to win in the fierce competition in jobs market, they must form the unique characteristics in the graduates' employment competitiveness.

\section{SUMMARY}

In this paper, the current development of private colleges is analyzed. With reference to the theories and methods of enterprise strategic management, the theoretical basis of the development of private colleges is studied. The internal and external advantages and disadvantages of private universities are analyzed. At last, the differential development strategy is presented, which provides theoretical and practical suggestions for the development of private universities.

\section{REFERENCES}

[1] Daniel Rodas, "Resource Allocation in Private Research Universities" [M].New York: Routledge. Falmer, pp12-15, 2001

[2] Leon G. Schiffman \& Leslie lazar Kanuk. Consumer Behavior (7th)[M].New York: Prentice Hall, pp 5-10, 2001

[3] David Middlewood and Jacky Lumby. Strategic Management in Schools and Colleges [M]. London: Paul Chapman Pub,pp21-28, 1998

[4] Leslie de Chernatong. From Brand Vision to Brand Evaluation[J].Batter Worth Heinemann, pp 26-89, 2001

[5] Fred R.David. Strategic Management: concepts tenth edition. Pearson Education,Inc.,2005

[6] Christopher R.Thomas, S.Charles Maurice. Managerial Economics, 8th edition. The McGraw-Hill Companies, Inc., 2007 